\title{
A clinical comparison of purified bovine and purified porcine insulins
}

\author{
S.A. Olczak and R.H. Greenwood ${ }^{1}$
}

University Department of Clinical Biochemistry, Addenbrooke's Hospital, Cambridge; 'Diabetic Clinic, Norfolk and Norwich Hospital, Norwich, UK.

\begin{abstract}
Summary: Twenty four patients with established insulin dependent diabetes treated with twice daily soluble and isophane bovine insulins were changed to equivalent doses of either purified bovine Neusulin and Neuphane (Wellcome) or purified porcine Actrapid and Monotard (Novo) insulins. After 6 months treatment the porcine group showed a $35 \%$ fall in insulin binding antibodies and a $14 \%$ reduction in insulin dosage. The group changed to purified bovine insulins showed no significant change in insulin binding antibodies and no change in insulin dose. Mean blood glucose and glycosylated serum protein fell in both groups during the study period but there was no significant difference between the two groups.
\end{abstract}

\section{Introduction}

The majority of patients treated with conventional bovine insulins develop circulating insulin antibodies and these may cause clinical complications (Reeves, 1980). Injection site lipoatrophy is a relatively common problem which may be related to insulin antibody deposition in the dermis and this condition may be reversed by changing to highly purified porcine insulin which is less immunogenic (Reeves, Allen \& Tattersall, 1980). The position regarding other possible effects of insulin antibodies is less clear. It has been suggested that they may reduce the length of the remission phase of insulin dependent diabetes (Anderson \& Egeburg, 1977), that they may be involved in the development of some of the longterm complications of diabetes (Andersen, 1976) and that they may contribute to the fetal macrosomia which occurs in some diabetic pregnancies (Falluca et al., 1980). Many of the conventional bovine insulins have recently been withdrawn by their manufacturers and replaced by purified bovine insulins, thus many patients have had their insulin preparations abruptly changed. The present study looks at the changes in insulin antibody levels, insulin dose and diabetic control in established insulin dependent diabetics changed from conventional bovine insulins to either purified bovine insulins or purified porcine insulins.

S.A. Olczak, B.Sc., M.B., B.S., M.R.C.P.; R.H. Greenwood, B.Sc., M.B., B.S., M.R.C.P.

Accepted: 15 May 1984

\section{Patients and methods}

Twenty four patients from the diabetic clinic at the Norfolk and Norwich Hospital were studied. Clinical details are given in Table I. They were insulin dependent diabetics who had been treated with twice daily soluble and isophane bovine insulins for at least $2 \mathrm{y}$. All patients were seen by one doctor throughout the study. During a run-in period of 2 months blood glucose control was improved by means of education, regular 4 times a day urine testing with self adjustment of insulin dose, and preprandial home capillary blood glucose profiles with adjustment of insulin dosage by the doctor. Diet was not altered. At 2 months alternate patients were changed to an equivalent dose of either purified bovine Neusulin and Neuphane (Wellcome) insulins or purified porcine Actrapid and Monotard (Novo) insulins. The patients were studied at entry and at 2 monthly intervals for a further 6 months.

Table I Patient details

Bovine group Porcine group

\begin{tabular}{lcc}
\hline $\begin{array}{l}\text { Number } \\
\text { Mean age (y) } \\
\text { (range) }\end{array}$ & 11 & 12 \\
$\begin{array}{l}\text { Mean \% ideal body wt. } \\
\text { (range) }\end{array}$ & $(29-48)$ & $(17-61)$ \\
$\begin{array}{l}\text { Mean duration of } \\
\text { diabetes (y) }\end{array}$ & 106 & 102 \\
(range) & $(84-125)$ & $(84-125)$ \\
& 17.5 & 16.7 \\
& $(10-28)$ & $(7-34)$
\end{tabular}


Home capillary blood glucose profiles were collected using Reflotest strips (Boehringer Mannheim) and read by the doctor the following day on a Reflomat meter. Validation of each individual patient's technique was performed during the 2 months run-in period by comparing the Reflotest results with simultaneous capillary glucose samples collected into small plastic tubes which were analysed the following day by a glucose oxidase method. Glycosylated protein was measured by the method of Metcalfe et al. (1983). Insulin binding antibodies were measured by a radioimmunoelectrophoretic method (Christiansen, 1973). ${ }^{125}$ I bovine insulin was obtained from Novo Laboratories Ltd. Sequential samples from each patient were measured together in the same batch to eliminate between batch variation and results are expressed as $\mu \mathrm{g}$ of insulin bound per litre of serum.

All results are expressed as mean \pm s.e.m. Statistical analysis was by the Student $t$-test.

\section{Results}

One patient in the bovine group was withdrawn from the study because he was unable to provide satisfactory home capillary glucose profiles after the first 4 months of the study. The final results relate to 11 patients transferred to purified bovine insulins and 12 patients transferred to purified porcine insulins.

\section{Diabetic control}

There was no significant difference in the frequency of clinical hypoglycaemic episodes between the 2 groups of patients. The major improvement in mean daily blood glucose (mean of 4 preprandial values) occurred during the 2 month run-in period (Table II). The 2 month mean glucose value for the porcine group was significantly lower $(P<0.05)$ than the mean glucose value for this group at entry to the study. The mean glucose at 2 months was also lower in the bovine group but this was not statistically significantly different from that at entry. There were no significant differences in mean blood glucose between the bovine and porcine groups. Mean glycosylated serum protein

Table II Mean blood glucose ( $\mathrm{mmol} / \mathrm{l})$ in the two groups

\begin{tabular}{lrcrrr}
\hline & \multicolumn{3}{c}{ non-purified } & \multicolumn{3}{c}{ purified } \\
Months & 0 & 2 & 4 & 6 & 8 \\
\hline Bovine (11) & 13.2 & 10.4 & 11.0 & 9.0 & 10.2 \\
\pm s.e.m. & 1.7 & 1.1 & 1.0 & 1.3 & 1.3 \\
Porcine (12) & 13.4 & $9.9 *$ & 9.5 & 8.5 & 9.1 \\
\pm s.e.m. & 1.1 & 1.3 & 0.7 & 1.2 & 1.0 \\
\hline
\end{tabular}

* $P<0.052$ months vs 0 months
Table III Mean glycosylated serum protein (nm fructose/ $\mathrm{mg}$ protein) in the two groups

\begin{tabular}{lccccc}
\hline & \multicolumn{3}{c}{ non-purified } & \multicolumn{3}{c}{ purified } \\
Months & 0 & 2 & 4 & 6 & 8 \\
\hline Bovine (11) & 4.10 & 3.55 & 3.33 & 3.81 & 3.46 \\
\pm s.e.m. & 0.51 & 0.25 & 0.38 & 0.51 & 0.59 \\
Porcine (12) & 4.78 & 4.68 & 3.73 & 4.44 & 3.49 \\
\pm s.e.m. & 0.40 & 0.69 & 0.39 & 0.51 & 0.64 \\
\end{tabular}

Normal range $1.38 \pm 0.7$ (mean \pm s.d.)

(Table III) fell in both groups during the study period, but remained above the normal range. The within group and between group differences were not significantly different. Glycosylated protein correlates significantly with glucose values in the preceding 1 to 4 weeks, and hence provides an estimation of recent overall control (Metcalfe et al., 1983).

\section{Insulin binding antibodies (Table IV)}

Nine patients in the bovine group and 11 patients in the porcine group had significant antibody production $(>20 \mu \mathrm{g} / 1)$ at entry to the study. There was no correlation between initial antibody level and initial insulin dose. The bovine group had a higher mean initial level but this difference was not statistically significant. Antibody levels in the bovine group did not change following conversion to purified insulin? whereas those in the porcine group fell, the 6 month value being significantly lower $(P<0.05)$ than the value at entry.

\section{Insulin dosage (Table $\mathrm{V}$ )}

The porcine group showed a $14 \%$ reduction in insulin dosage at 8 months. There was no change in total dosage in the bovine group but as with the porcine group an increased proportion of insulin was of the medium-acting type. Most of this change in insulin dosage and in distribution between short and medium acting insulins occurred during the 2 month run-in

Table IV Insulin binding antibodies $(\mu \mathrm{g} / 1)$ in the two groups

\begin{tabular}{lccccc}
\hline & \multicolumn{3}{c}{ non-purified } & \multicolumn{3}{c}{ purified } \\
Months & 0 & 2 & 4 & 6 & 8 \\
\hline Bovine (11) & 83 & 82 & 87 & 86 & 88 \\
\pm s.e.m. & 27 & 26 & 29 & 27 & 26 \\
Porcine (12) & 66 & 67 & 48 & $40^{*}$ & 43 \\
\pm s.e.m. & 11 & 10 & 8 & 5 & 6 \\
\hline
\end{tabular}

* $P<0.056$ months vs 0 months 
Table V Insulin dosage - units (mean \pm s.e.m.)

\begin{tabular}{clll}
\hline Bovine & Short acting & $36 \pm 5$ & $32 \pm 4$ \\
$(11)$ & Medium acting & $20^{*} \pm 3$ & $25 \pm 4$ \\
Porcine & Short acting & $38 \pm 5$ & $30 \pm 4$ \\
$(12)$ & Medium acting & $28^{*} \pm 6$ & $27 \pm 4$ \\
\hline
\end{tabular}

*NS

period, and is likely therefore to have been an effect of the patient education and consequent improved control.

\section{Discussion}

The immunological response to injected insulin is determined by the type and degree of contamination of the preparation, by structural differences in the insulin molecule itself and by the inherent immune responsiveness of the individual patient (Fineberg et al., 1983). Controversy exists concerning the harmful or beneficial effects of insulin binding antibodies, and several complications of insulin therapy are related to circulating insulin antibodies. Massive insulin resistance is a rare phenomenon but high antibody levels are often present in patients with this condition. The commonest complication is local cutaneous allergy to insulin and injection site lipoatrophy (Reeves, 1980).

The pharmacokinetics of exogenously administered insulin may be altered by the presence of insulin binding antibodies, and Harwood (1960) has suggested that release of insulin from insulin antibody complexes may be unpredictable and lead to hypoglycaemia. On the other hand Vaughan et al. (1983) have shown that patients with high titres of insulin binding antibodies take longer to decompensate metabolically when insulin is discontinued than a low antibody producing group. It has also been suggested that insulin antibody complexes may form a reservoir for insulin release and hence improve control of diabetes (Dixon et al., 1974).

Insulin antibodies may reduce endogenous insulin secretion and hence shorten the remission phase in newly diagnosed diabetes (Andersen and Egeburg, 1977). Reduction of endogenous insulin secretion may result in greater difficulty in controlling blood glucose. However, Yue et al. (1978) have shown that there is no difference in residual $\mathrm{C}$-peptide secretion in patients with and without insulin antibodies. There is also evidence that patients with retinopathy and diabetic nephropathy have an increased prevalence of high antibody titres and Andersen (1976) suggested that the nephropathy might be due to immune complex deposition. However, many non-insulin dependent diabetics who have never received exogenous insulin also have these complications.

Several studies have looked at the effect of changing from conventional bovine to purified porcine insulin preparations, but not all have shown a relationship between changes in insulin binding antibodies and a reduction in insulin dose. Walford, Allison and Reeves (1982) reported that patients with low initial insulin binding antibodies do not respond to a change in insulin type either by a change in dose, diabetic control, or insulin binding antibodies. In addition many workers have confirmed the heterogeneity of the immune response to injected insulin and there is an association with certain HLA phenotypes (Sklenar $e t$ al., 1982). DR3 carriers have a low antibody response to porcine but not to bovine insulin. DR4 and DR3/4 carriers have a high antibody response to bovine and porcine insulin.

The present study has confirmed the experience of others that improvement in control of diabetes when changing to a new insulin regimen is largely due to improved education and the increased attention given to patients. Insulin binding antibodies fell in the group changed to porcine insulin but there was no change in the bovine group. Possible explanations for this finding are differences in the purity of the insulin preparations or the molecular differences between bovine and porcine insulins. Studies using bovine and porcine insulins with the same degree of purity have indicated a lower antibody response in the patients treated with porcine insulin (Graber and Frankhauser, 1978). Nevertheless, in the present study, despite higher levels of insulin binding antibodies in the bovine group there was no evidence of poorer control in this group.

In summary we have shown that changing patients from conventional bovine insulin to purified bovine insulin does not require a change in insulin dose and does not reduce the levels of insulin binding antibodies, whereas when patients are changed to purified porcine insulin there is a reduction in dosage of approximately $15 \%$ and insulin binding antibodies fall by one third within 6 months.

\section{Acknowledgements}

We would like to thank Staff Nurse Julia Tweedie for clinical assistance, Margaret Loke for measuring the insulin binding antibodies, Joan Metcalfe for the glycosylated protein estimations, the Biochemistry Department at the Norfolk and Norwich Hospital, and Professor C.N. Hales for advice and criticism. The Wellcome Foundation Ltd provided financial support. 
References

ANDERSEN, O.O. (1976). Anti-insulin antibodies and late diabetic complications. Acta Endocrinologica, 83, 329.

ANDERSEN, O.O. \& EGEBURG, J. (1977). The clinical significance of insulin antibodies. Acta Paediatrica Scandinavica (Supplement), 270, 63.

CHRISTIANSEN, Aa.H. (1973). Radioimmunoelectrophoresis in the determination of insulin binding to IgG. Methodological studies. Hormone and Metabolic Research, 5, 147.

DIXON, K., EXON, P.D., \& MALINS, J.M. (1975). Insulin antibodies and the control of diabetes. Quarterly Journal of Medicine, 44, 543.

FALLUCA, F., PACHI, A., GERLINI, G., GIANGRANDE, L., SCARCIOTTA, O., PEDULLA, C., PINTOR, A. \& LAVICOLI, M. (1980). Placental transfer of IgG insulin antibodies and metabolic and clinical complications in the I.D.M.s. (Abstract) Diabetologia, 19, 273.

FINEBERG, E.S., GALLOWAY, J.A., FINEBERG, N.S. \& GOLDMAN, J. (1983). Effects of species of origin, purification levels, and formulation on insulin immunogenicity. Diabetes, 32, 592.

GRABER, D. \& FRANKHAUSER, S. (1978). Antigenicity of some new chromatographically purified depot insulins. Schweizerische Medizinische Wochenschrift, 180, 1807.

HARWOOD, R. (1960). Insulin binding antibodies and 'spontaneous' hypoglycaemia. New England Journal of Medicine, 262, 978.
METCALFE, J., BROOKS, A.P. \& DAY, J.L. (1983). Glycosylated protein - a better index of preceding glucose control in diabetes? (Abstract) Medical and Scientific Section of the British Diabetic Association, Spring Meeting, York.

REEVES, W.G. (1980). Immunology of diabetes and insulin therapy. In Recent Advances in Clinical Immunology, Thompson, R.A. (ed)., 2, p183 Churchill Livingstone: Edinburgh.

REEVES, W.G., ALLEN, B.R. \& TATTERSALL, R.B. (1980). Insulin-induced lipoatrophy; evidence for an immune pathogenesis. British Medical Journal, 280, 1500.

SKLENAR, I., NERI, T.M., BERGER, W. \& ERB, P. (1982). Association of specific immune response to pork and beef insulin with certain HLA-DR antigens in Type 1 diabetes. British Medical Journal, 285, 1451.

VAUGHAN, N.J.A., MATHEWS, J.A., KURTZ, A.B. \& NABARRO, J.D.N. (1983). The bioavailability of circulating antibody-bound insulin following insulin withdrawal in Type 1 (insulin dependent) diabetes. Diabetologia, 24, 355.

WALFORD, S., ALLISON, S.P. \& REEVES, W.G. (1982). The effect of insulin antibodies on insulin dose and diabetic control. Diabetologia, 22, 106.

YUE, D.K., BAXTER, R.C. \& TURTLE, J.R. (1978). C-peptide secretion and insulin antibodies as determinants of stability in diabetes mellitus. Metabolism, 27, 35. 